\title{
Elektromyografi og nevrografi ved alvorlig nevromuskulær sykdom
}

\author{
BAKGRUNN Mange nevromuskulære sykdommer er potensielt alvorlige, og elektromyografi \\ (EMG) og nevrografi er metoder som benyttes i utredningen av disse tilstander.
}

KUNNSKAPSGRUNNLAG Artikkelen er basert på forfatternes kunnskaper og erfaringer, med spesiell vekt på metodenes anvendelse i utredningen av alvorlige sykdommer i tverrstripet muskulatur og i perifere nerver. Det ble gjennomført et litteratursøk i PubMed med begrensning 15 år bakover i tid. I tillegg har vi gjort et skjønnsmessig utvalg av artikler som vi kjente til.

RESULTATER Ved utredning av myopati er EMG mest verdifull, og ved nevropati gir nevrografi mest informasjon, men metodene utfyller hverandre. Ved enkelte tilstander er undersøkelsene de mest sensitive for diagnosen (for eksempel myasteni). Høy kompetanse er nødvendig for diagnostisering av de omtalte tilstandene.

FORTOLKNING EMG og nevrografi er viktige og ofte nødvendige undersøkelser i utredning av pasienter med alvorlig nevromuskulær sykdom.

Elektromyografi (EMG) og nevrografi er viktige undersøkelsesmetoder ved utredning av nevromuskulære sykdommer. Perifere nerver og muskulatur er eksitable vev hvor endringer i membranpotensialet er viktig for deres funksjon. Ved de aller fleste sykdommer i muskulatur og perifere nerver skjer det endringer i den elektrofysiologiske funksjonen som kan registreres ved de nevnte metoder. EMG og nevrografi er dynamiske undersøkelser som avslører typer av funksjonsforstyrrelser, og de kan i tillegg gi opplysninger som også indikerer strukturelle forandringer. Ved enkelte nevromuskulære sykdommer er EMG og nevrografi de eneste metodene som kan påvise patologi og dermed gi grunnlag for å stille diagnose.

Indikasjonen for $\mathrm{EMG} /$ nevrografi vil generelt være en klinisk mistanke om sykdom i perifere nerver og/eller i muskulatur hos pasienter i alle aldersgrupper. Undersøkelsene kommer vanligvis tidlig i utredningen. EMG vil ofte være mest aktuelt å utføre ved muskelsykdommer, mens nevrografi er mest verdifull ved diagnostisering og klassifisering av sykdommer og lesjoner i det perifere nervesystem. Imidlertid vil begge metoder kunne gi verdifull informasjon om sykelige forandringer $\mathrm{i}$ begge disse organsystemer. Oftest vil det være indisert å gjøre både EMG og nevrografi. Resultatet av undersøkelsene vurderes sammen for å få best mulig informasjon om nevromuskulær status.

Hensikten med artikkelen er å gi en kort beskrivelse av disse nevrofysiologiske metodene og informere om deres nytte og begrensninger ved diagnostikk av nevromuskulær sykdom med spesiell vekt på noen av de alvorlige sykdommene.

\section{Kunnskapsgrunnlag}

Artikkelen er basert på forfatternes kunnskaper og erfaringer med EMG og nevrografi og metodenes anvendelse i utredningen av sykdommer i tverrstripet muskulatur og i perifere nerver. I tillegg er det gjort et skjønnsmessig utvalg av artikler som forfatterne kjente til (først og fremst om metodene), og det ble gjennomført litteratursøk i PubMed med begrensning 15 år bakover i tid. Følgende søkeord ble brukt: «EMG» og/eller «nerve conduction studies» eller «electrophysiology» $\mathrm{i}$ kombinasjoner med «polyneuropathy and sensitivity or utility», "small fiber neuropathy», «Guillain-Barre», «ALS and diagnostic criteria», "acute neuromuscular respiratory failure», "neuromuscular transmission and usefulness». I tillegg søkte vi på «critical illness myopathy neuropathy and review and prognosis», "LEMS myasthenia gravis and pathogenesis», «LEMS and lung tumor», «distal myopathy review», "central core disease and malignant hyperthermia review».

Søket ble avsluttet 1.6. 2012, og i alt ble 410 artikler funnet. Artiklene som ble valgt ut var engelsk- eller norskspråklige og tilgjengelig på Internett eller Universitetsbiblioteket i Tromsø. Vi la vekt på artiklenes innhold og budskap og sannsynlige leseres interesse. I tillegg til artiklene som ble valgt ut etter søket, ble seks artikler som forfatterne kjente til fra før inkludert.

\section{EMG og nevrografi}

EMG er registrering av elektrisk aktivitet i tverrstripet muskulatur. En tynn nål med registrerende elektrode montert på nålespissen stikkes inn i aktuell muskel (illustrasjonen, øverst). Det registreres elektrisk aktivitet nær muskelcellene i hvile og ved

\author{
Sissel Løseth \\ sissel.loseth@unn.no \\ Nevrologisk- og nevrofysiologisk avdeling \\ Universitetssykehuset Nord-Norge \\ og \\ Institutt for klinisk medisin \\ Universitetet i Troms $\emptyset$
}

Torberg Torbergsen

Nevrologisk- og nevrofysiologisk avdeling

Universitetssykehuset Nord-Norge

\section{HOVEDBUDSKAP}

EMG og nevrografi er verdifulle og ofte nødvendige undersøkelser ved diagnostikk av nevromuskulær sykdom

EMG og nevrografi kan være de mest sensitive diagnostiske metodene

Høy kompetanse på metodene og deres anvendelse er nødvendig i utredning av disse alvorlige og sjeldne tilstandene 

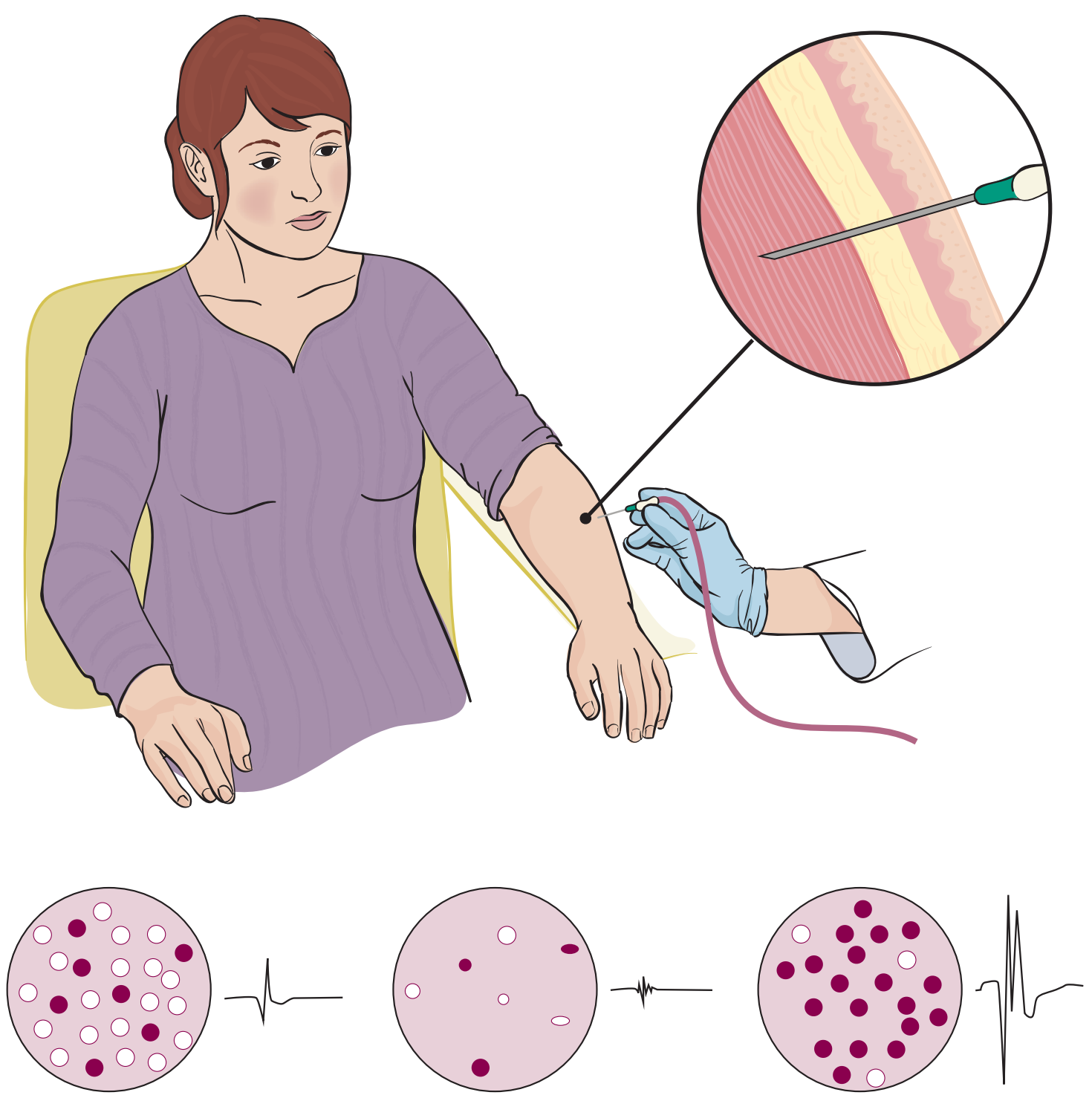

EMG-undersøkelse. Vanligvis brukes såkalt konsentrisk nåleelektrode der den registrerende elektroden ligger sentralt i nålen og kommer ut på spissen, mens nålens skaft fungerer som referanse. De elektriske signalene ledes fra nålen inn i EMG-apparatet der potensialene forsterkes og kan studeres visuelt (på skjermen) og auditivt (fra en høyttaler). Undersøkelsen foretas med muskelen i hvile og med varierende grad av voluntær kontraksjon, og nålens posisjon endres flere ganger $i$ hver muskel. Illustrasjonen skisserer også et tverrsnitt av EMG-nålens opptaksområde i muskelen og motorisk enhets-potensialer hos normal person la), pasient med myopati (b) og pasient med nevropati (c). Muskelceller som er illustrert med farge, tilhører samme motoriske enhet. Ved myopati ses motorisk enhets-potensialer med lav amplitude og kort durasjon på grunn av degenererte muskelceller. Ved nevropati har det motoriske nevronet til de fargede muskelcellene reinnervert andre muskelceller som har mistet sin innervasjon. Dette medfører en motorisk enhet med økt antall fargede muskelceller, og motorisk enhets-potensialer blir høyamplitudig med økt durasjon. Illustrasjon @ J. Engqvist/llumedic
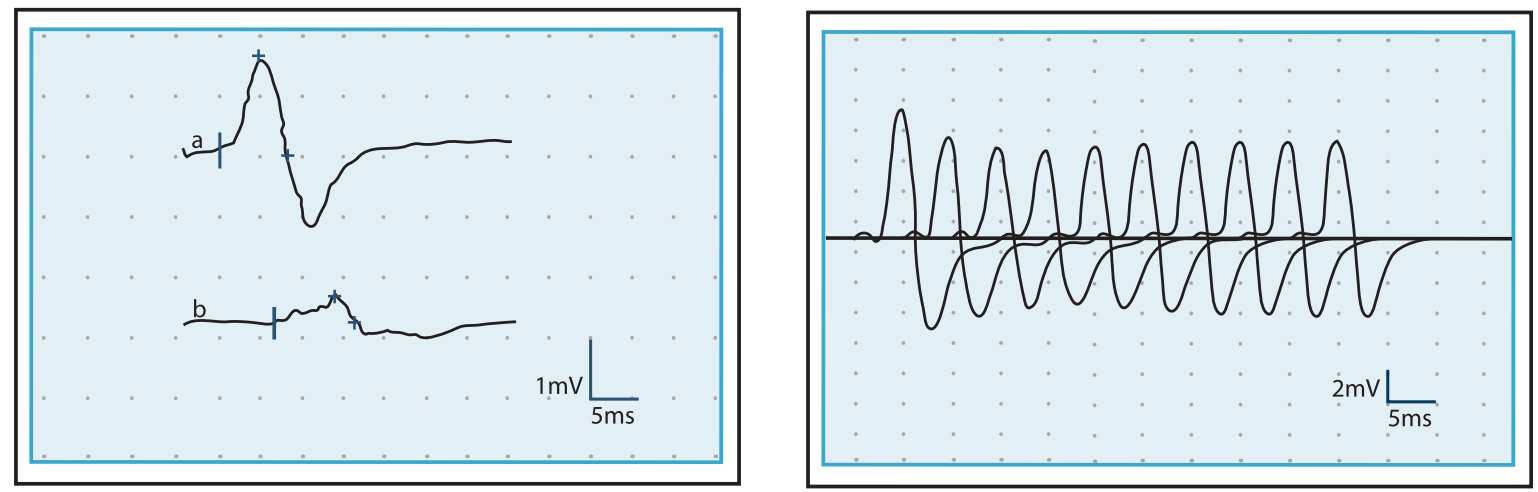

Til venstre ses resultater fra nevrografi av medianusnerven hos en pasient med immunologisk demyeliniserende polynevropati. Nerven stimuleres ved håndleddet lal og ved albuen (b), og motorisk svarpotensial registreres over medianusinnervert thenarmuskulatur. Det er $70 \%$ lavere amplitude ved proksimal stimulering lalbuen) sammenliknet med distal (håndleddet). Det skyldes demyelinisering i nerven som giør at impulsen i mange nevroner blokkeres og gir ledningsblokk. Til høyre vises utskrift av repetitiv nervestimulering hos pasienten med myasthenia gravis (ramme 1). Stimulering av $n$. tibialis (10 støt, $3 \mathrm{~Hz}$ ), og registrering over fotmuskulatur viser et dekrement (reduksjon i motorisk amplityde) på $33 \%$, som er tegn på forstyrret nevromuskulær transmisjon. Illustrasjon @ J. Engqvist/llumedic 
voluntær kontraksjon av muskelen. Spontanaktivitet er en samlebetegnelse på ulike typer patologisk elektrisk aktivitet som registreres når muskelen er i hvile. Hyppigste form er såkalt denervasjonsaktivitet. Dersom en muskelcelle mister sin innervasjon, vil det gradvis skje en endring av cellemembrankvaliteten med blant annet økt følsomhet for acetylkolin. Etter 10-12 dager vil det opptre spontan depolarisering i muskelfiberen, noe man kan registrere med EMGnålen. Forandringer i muskelcellemembranen ved spesielle sykdommer som myotoni og nevromyotoni gir karakteristiske funn.

Når pasienten aktiverer muskelen, vil muskelfibre som tilhører den samme motoriske enhet, kontraheres samtidig. Summasjonen av disse enkeltfiberpotensialene danner et såkalt motorisk enhets-potensial (illustrasjonen, øverst). Det finnes normalkriterier for bredde, amplitude og antall faser (1). Ved affeksjon av tilførende nerve vil motorisk enhets-potensialene i prinsippet være økt i amplitude og bredde og mer eller mindre polyfasiske, det vil si oppsplittede $i$ form på grunn av dårligere synkroniserte utladninger av de enkelte muskelfiberpotensialene i den motoriske enhet. Primær muskelsykdom karakteriseres oftere av potensialer med kortere og vanligvis lavere amplitude (2).

Når pasienten øker kontraksjon av muskelen, vil den enkelte motoriske enhet fyre raskere og nye motoriske enheter rekrutteres. Nevropati vil medføre redusert rekruttering på grunn av tap av nevroner, mens det ved myopati vil være tidlig rekruttering som kompensasjon for redusert kraft $\mathrm{i}$ den enkelte motoriske enhet $(2,3)$.

Nevrografi er undersøkelse av funksjonen i motoriske og sensoriske nerver. Oftest benyttes overflateelektroder både til stimulering og registrering etter et fast oppsett (4-6). Metoden beskrives mer utfyllende i en annen artikkel i dette nummeret (7).

Nedsatt ledningshastighet ses ved affeksjon av nervens myelinskjede, mens normal ledningshastighet og redusert amplitude av svarpotensial er mer typisk for aksonal lesjon $(4,6)$. Ved stimulering av den motoriske nerven vil impulsen også ledes i proksimal retning og gi opphav til såkalte sene responser. Disse kan gi informasjon om den proksimale delen av nerven $(4,5)$.

\section{Muskelsykdommer}

Muskeldystrofier er genetisk betingede muskelsykdommer som vanligvis har et langsomt progredierende forløp. Utviklingen innen medisinsk genetikk har gjort det mulig å inndele disse i en rekke forskjellige grupper basert på påvisning av ulike genfeil som medfører endrede proteiner. Dette medvirker også til å gi informasjon om ulike patofysiologiske mekanismer og arvegang.

EMG er en undersøkelse som kommer inn i tidlig fase ved klinisk mistanke om disse sykdommene, både for å avklare om det foreligger en myopati eller ikke, for planlegging av mulig muskelbiopsi og eventuelt som guide for egnet sted for dette og for strategi for videre genetisk utredning. EMG vil i liten grad kunne skille mellom ulike typer av muskeldystrofi.

En langsomt progredierende polymyositt kan være vanskelig med sikkerhet å atskille fra en muskeldystrofi - både klinisk, ved EMG og også ved biopsi. Som ved muskeldystrofi får man ved EMG myopatiske motorisk enhets-potensialer. Ved polymyositt kan avsplittede muskelfibre gi opphav til enkeltfiberpotensialer, slik som denerverte muskelfibre gjør. Kombinasjon av myopatisk mønster (som ved muskeldystrofi) og spontanaktivitet kan altså tale i retning av at det foreligger en polymyositt.

Pasienter med langsom progressiv muskulær distal atrofi og parese får ikke sjelden klinisk diagnosen polynevropati, for eksempel av typen Charcot-Marie-Tooth-sykdom En EMG-undersøkelse vil enkelt kunne avgjøre om det i stedet foreligger en form for distal myopati. En korrekt diagnose er viktig som grunnlag for genetisk veiledning. Enkelte typer i denne sykdomsgruppen kan være forbundet med alvorlig hjertesykdom (desminopatier), mens andre typer (central core disease) vil være disponert for alvorlige komplikasjoner som malign hypertermi i forbindelse med anestesi $(8,9)$.

Ved ionekanalsykdommer i muskulatur og perifere nerver er EMG det suverene diagnostiske verktøyet. Myotoni med stivhet og treghet i muskulaturen kan være vanskelig å påvise klinisk, og verken biopsi eller bildediagnostikk vil være til stor hjelp. EMG vil entydig vise de karakteristiske spontane repetitive elektriske utladningene (2).

Mangel på patologiske funn ved EMG kan også være til diagnostisk hjelp. Ved klinisk sannsynlig myopati vil normale EMG-funn kunne tale i retning av metabolsk myopati, fordi det ved denne tilstanden er lite strukturelle forandringer i muskelcellene. Ved autoimmunt stivhetssyndrom er det kliniske bildet ofte dramatisk, men EMG er overraskende nok normalt (10). Uttalte ufrivillige muskelkontraksjoner uten registrerbar elektrisk aktivitet ved EMG er mest forenlig med den forholdsvis sjeldne Torbergsens sykdom (rippling muscle disease) (11).

\section{Perifere nervesykdommer}

Nevrografi og EMG er av stor diagnostisk verdi ved klinisk mistanke om polynevropati. I tillegg til å få bekreftet at pasienten har polynevropati, sier undersøkelsene noe om distribusjon av forandringer og alvorlighetsgrad. Svært viktig for å kunne finne årsak til polynevropati er å påvise om det foreligger hovedsakelig demyelinisering eller aksonal skade. I denne kartleggingen vil nevrografi og EMG som metoder utfylle hverandre, men nevrografi må anses som den som totalt sett gir mest informasjon (12). Ved motorisk aksonal nevropati kan nevrografi være nor- mal, og EMG er da en mer sensitiv metode for å påvise tilstanden. I tillegg gir EMG viktig tilleggsinformasjon, da forekomst av spontanaktivitet og instabile motorisk enhetpotensialer taler for en aktiv og mer alvorlig sykdomsprosess (2). EMG vil også kunne avdekke annen nevromuskulær sykdom som årsak til pasientens symptomer (for eksempel myopati). Det er viktig å være oppmerksom på at ved isolert tynnfibernevropati, ofte ledsaget av nevropatiske smerter, vil EMG/ nevrografi gi normale funn (13).

Polynevropati er i de fleste tilfeller en langsomt progredierende tilstand, og de færreste får alvorlige og invalidiserende nevrologiske utfall. Selv om symptomer og funn ved klinisk nevrologisk undersøkelse vanligvis er typiske, vil EMG og nevrografi kunne gi en mer sikker og spesifikk diagnose som kan være til hjelp i den videre utredning (14). Ett eksempel kan være multippel mononevropati med spredte lesjoner $\mathrm{i}$ flere perifere nerver. Slike pasienter må utredes videre med tanke på mulig bakenforliggende vaskulitt. Paraneoplastisk polynevropati er som oftest raskt progredierende og affiserer spesielt sensoriske nerver.

Primært demyeliniserende polynevropati har to hovedgeneser: hereditær og immunologisk. Nevrografi kan som regel skille mellom disse to gruppene. Hereditær demyeliniserende polynevropati kan ha svært langsomme ledningshastigheter, men oftest uten konduksjonsblokk fordi det er en jevn demyelinisering langs hele nerven (4). Diagnosen kan ofte bekreftes ved molekylærgenetisk utredning. Akutte og kroniske immunologiske demyeliniserende polynevropatier har typisk konduksjonsblokk, men det finnes unntak. Det er viktig å påvise en sannsynlig immunologisk polynevropati, fordi den kan behandles (15).

Akutt inflammatorisk poly(radikulo)nevropati (Guillain-Barrés syndrom) er en alvorlig og potensielt dødelig form for polynevropati, da respirasjon og det autonome nervesystemet kan påvirkes. Årsaken er autoimmun, og tilstanden ses som regel i forløpet etter en infeksjon. Symptomer er raskt progredierende pareser, eventuelt sensoriske utfall og autonome symptomer. Nevrografi og EMG spiller en nøkkelrolle for diagnose og klassifisering av tilstanden. Guillain-Barrés syndrom deles i to hovedgrupper: akutt inflammatorisk demyeliniserende polynevropati, som er den vanligste formen, og akutt motorisk aksonal polynevropati.

Nevrografi vil hos de fleste etter få dager vise patologiske funn (16). Ved akutt inflammatorisk demyeliniserende polynevropati finnes tegn på demyelinisering der de tidligste funnene er abnormale sene responser som tegn på proksimal demyelinisering i nervene, og i tillegg reduserte ledningshastigheter samt konduksjonsblokk grunnet fokal demyelinisering (illustrasjonen, nederst). Typisk er de motoriske parametrene ved nevrografi mer patologiske enn de sensoriske til tross for at pasienten kan ha nokså uttalte parestesier. 
Nervus suralis er i mange tilfeller normal (16). Ved akutt motorisk aksonal polynevropati domineres nevrografifunnet av lave motoriske amplituder. EMG vil først etter to uker vise denervasjonsaktivitet forenlig med akutt aksonal skade. Det er viktig å være oppmerksom på at reversibelt konduksjonsblokk kan ses de første tre ukene ved akutt motorisk aksonal polynevropati forårsaket av forbigående ledningsblokk i aksonene ved Ranviers knuter (17). Dette kan medføre en underdiagnostisering av akutt motorisk aksonal polynevropati til fordel for akutt inflammatorisk demyeliniserende polynevropati. Kontroll av EMG/nevrografifunn etter noen uker er anbefalt $(17,18)$.

\section{Amyotrofisk lateral sklerose}

Amyotrofisk lateral sklerose er en progredierende og fatal nevrodegenerativ sykdom som rammer de motoriske forhorncellene og de sentrale motoriske banene i hjerne og ryggmarg. Ved det klassiske kliniske bildet ses en blanding av sentrale (for eksempel hyperrefleksi) og perifere motoriske utfall (parese/ atrofi/fascikulasjoner). Diagnostiske kriterier bygger på funn ved klinisk undersøkelse og nevrofysiologisk utredning. Sikker sykdom defineres som kliniske eller nevrofysiologiske tegn på nedre og øvre motornevronaffeksjon i bulbær muskulatur og i minst to spinale regioner (cervikal, torakal, lumbal) eller i tre spinale regioner (19).

Nevrofysiologisk utredning er spesielt nyttig når man påviser sykdomsaktivitet i muskulatur i en region som ikke er klinisk affisert. Ved nevrografi finnes lave motoriske amplituder, og sideasymmetri er initialt vanlig. Ledningshastigheter er normale eller tilnærmet normale $(19,20)$. Sensoriske parametre er oftest normale, men en viss sensorisk affeksjon har vært rapportert (21). EMG viser nevrogene potensialer med økt amplitude, polyfasi og ofte med såkalte instabile komponenter som tegn på aktiv reinnervasjon. Rekruttering av motorisk enhet-potensialer er redusert på grunn av tap av motoriske enheter. Ifølge kriteriene skal det i muskulatur med nevrogene forandringer også være spontanaktivitet $\mathrm{i}$ hvile som tegn på pågående denervasjon. For å øke diagnostisk sensitivitet har man sidestilt fascikulasjonspotensialer med annen spontanaktivitet (19). Dette har vist seg å øke sensitiviteten spesielt hos pasienter med bulbær symptomdebut (22). EMG i bulbær muskulatur utføres ofte i tungemuskelen. Det kan være vanskelig å vurdere tilstedeværelse av spontanaktivitet, mest fordi pasienten ikke klarer å slappe helt av i tungen. EMG i musculus trapezius kan være et alternativ (23).

\section{Myasthenia gravis og \\ Eaton-Lamberts syndrom}

Dette er sjeldne og alvorlige tilstander forårsaket av danning av autoantistoffer som angriper reseptorer i den nevromuskulære synapsen (postsynaptiske acetylkolinresep- torer ved myasteni og presynaptiske spenningsstyrte kalsiumkanaler ved Eaton-Lamberts syndrom) (24). Sistnevnte sykdom er i over halvparten av tilfellene assosiert med småcellet lungekreft som ofte ikke er diagnostisert når syndromet påvises (25).

Ved nevrofysiologisk utredning utføres en spesiell type EMG (enkeltfiber- EMG) som er den mest sensitive undersøkelsen for påvisning av forstyrret nevromuskulær transmisjon (26). Det kan påvises patologi i muskulatur som klinisk er uaffisert. En EMG-nål med en liten registrerende flate benyttes, og ved spesielle registreringer måles patologisk stor tidsvariasjon i impulsoverføringen til muskelfibrene (økt «jitter»). En annen og mindre sensitiv metode er repetitiv nervestimulering. Oppsettet er som ved vanlig motorisk nevrografi bortsett fra at nerven stimuleres med gjentatte elektriske støt (ofte $3 \mathrm{~Hz}$ ). Man vil da måle en avtakende amplitude som tegn på svikt i transmisjonen (dekrement) (illustrasjonen, nederst). Ved Eaton-Lamberts syndrom vil stimulering med raskere frekvens $(20-50 \mathrm{~Hz})$ gi en økende amplitude (inkrement).

Typiske symptomer på myasteni er økt muskulær trettbarhet som blant annet kan gi varierende dysartri, diplopi og ptose, og i mer alvorlige tilfeller respirasjonssvikt. Atypisk klinisk presentasjon forekommer (ramme 1).

\section{Pasienter i intensivavdeling}

Nyoppståtte lammelser og/eller alvorlig respirasjonssvikt som krever intensiv behandling kan ha ulike årsaker. Noen pasienter med primær nevromuskulær sykdom kan utvikle alvorlig respirasjonssvikt. Serrano \& Rabinstein kartla årsaker til akutt respirasjonssvikt hos 85 pasienter med nevromuskulær sykdom (27). $55 \%$ var ikke diagnostisert før intensivbehandling ble iverksatt. Av disse var Guillain-Barrés syndrom den hyppigste diagnosen $(26 \%)$, etterfulgt av amyotrofisk lateral sklerose $(17 \%)$ og deretter myasteni og myopatier. De konkluderte med at EMG var den undersøkelsen som hadde størst diagnostisk verdi.

Andre har ingen tilgrunnliggende nevromuskulær sykdom. Polynevropati ved kritisk sykdom («critical illness»-polynevropati, CIP) og myopati ved kritisk sykdom («critical illness»-myopati, CIM) ses hos pasienter som har gjennomgått alvorlig sykdom, ofte med sepsis og multiorgansvikt. Pasienten blir bedre av dette, men utvikler uttalte lammelser, inkludert i respirasjonsmuskulatur, noe som fører til at pasienten vanskelig kan vennes av respirator. Årsaken er multifaktoriell og involverer blant annet metabolske og inflammatoriske mekanismer (28). EMG og nevrografi viser funn som ved en uttalt akutt aksonal polynevropati og/ eller akutt myopati (28). Hos de fleste er prognosen bra. Enkelte studier viser bedre prognose ved CIM $(29,30)$. Ved standard nevrofysiologisk undersøkelse kan det være

\section{RAMME 1}

\section{Kasuistikk}

En kvinne i 20-årene var henvist til nevrofysiologisk utredning grunnet sannsynlig myopati. Hun hadde de siste 4-5 år utviklet gradvis økende svakhet i muskulatur i underekstremitene, først og fremst proksimalt, men også distalt i legg/fot. Gangen var vaggende, og Trendelenburgs test var positiv. Det var ingen okulære symptomer. Muskelbiopsi hadde vist calpainmangel (Western blot), og tilstanden var blitt oppfattet som skulder-hofte (limb-girdle)-muskeldystrofi type 2a. Hun var blitt forberedt på en fremtidig langsom invalidisering og hadde planlagt sin utdanning med bakgrunn i dette. Nevrofysiologisk utredning viste imidlertid overraskende funn som ved myasthenia gravis med uttalt dekrement (illustrasjonen, nederst). Det ble videre påvist svært høye antistoffer mot acetylkolinreseptor. Pasienten ble thymektomert og medikamentelt behandlet og er i dag nærmest symptomfri.

Calpain er et relativt flyktig protein som lett kan «forsvinne» fra en biopsi og gi et negativt resultat, noe som sannsynligvis har skjedd her. I dette tilfellet med et atypisk sykdomsbilde og misvisende biopsiresultat var det EMG- og repetitiv nervestimulering som førte til rett diagnose. Dette fikk som ventet behandlingsmessige konsekvenser, og pasienten kunne planlegge en fremtid uten tiltakende invaliditet.

Pasienten har gitt samtykke til at kasuistikken blir publisert.

vanskelig å skille mellom de to former. Nevrografi viser ved begge tilstander lave motoriske amplituder, og EMG viser spontanaktivitet. Når pasienten er paralytisk eller uttalt paretisk, er det ofte ikke mulig å gjøre motorisk enhet-potensialanalyse. I motsetning til ved CIP er de sensoriske amplituder vanligvis normale ved CIM, men subkutane ødemer kan medføre at amplitudene blir falskt lave. En metode som kan være til hjelp, er å vurdere utseendet av motorisk respons ved vanlig nevrografi, da morfologien kan endres ved CIM (31).

\section{Konklusjon}

Et velfungerende klinisk nevrofysiologisk laboratorium er nærmest en forutsetning for å kunne drive nevromuskulær diagnostikk på en tilfredsstillende måte - både ved diagnostisering og kartlegging av relativt «vanlige» polynevropatier og innklemmingssyndromer, men ikke minst der høy EMG-kompetanse kan være nødvendig for diagnostisering av alvorlige og sjeldne tilstander som for eksem- 
pel Eaton-Lamberts syndrom, myasthenia gravis og poly/dermatomyositt.

Metodene vil også ofte være velegnet til evaluering av behandlingseffekt ved enkelte av disse sykdommene og er vel de eneste tekniske metodene vi har for å kartlegge funksjonen i det nevromuskulære apparatet. Forbedrede metoder innen biopsidiagnostikk og den raske utviklingen innen avansert molekylærgenetikk har sammen med avanserte nevrofysiologiske teknikker medvirket til betydelige fremskritt ved utredning av nevromuskulære sykdommer.

\section{Sissel Løseth (f. 1962)}

er ph.d. og spesialist i nevrologi og klinisk nevrofysiologi. Hun er seksjonsoverlege og har en bistilling ved Institutt for klinisk medisin. Forfatter har fylt ut ICMJE-skjemaet og oppgir ingen interessekonflikter.

\section{Torberg Torbergsen (f. 1937)}

er spesialist i nevrologi og klinisk nevrofysiologi og er professor emeritus.

Forfatter har fylt ut ICMJE-skjemaet og oppgir ingen interessekonflikter.

\section{Litteratur}

1. Stålberg E, Nandedkar SD, Sanders DB et al. Quantitative motor unit potential analysis. J Clin Neurophysiol 1996; 13: 401-22.

2. Stålberg E, Falck B. The role of electromyography in neurology. Electroencephalogr Clin Neurophysiol 1997: 103: 579-98.

3. Sanders DB, Stålberg EV, Nandedkar SD. Analysis of the electromyographic interference pattern. J Clin Neurophysiol 1996; 13: 385-400.
4. Kane NM, Oware A. Nerve conduction and electromyography studies. J Neurol 2012; 259: 1502-8.

5. Bischoff C. Neurography: late responses. Muscle Nerve 2002: 999 (suppl 11): S59-65.

6. Mallik A, Weir Al. Nerve conduction studies: essentials and pitfalls in practice. J Neurol Neurosurg Psychiatry 2005; 76 (suppl 2): ii23-31.

7. Todnem K, Sand T. Nevrografi ved karpaltunnelsyndrom. Tidsskr Nor Legeforen 2013; 133: 170-3.

8. Udd B, Griggs R. Distal myopathies. Curr Opin Neurol 2001; 14: 561-6.

9. Klingler W, Rueffert H, Lehmann-Horn F et al. Core myopathies and risk of malignant hyperthermia. Anesth Analg 2009; 109: 1167-73.

10. Holmøy T, Horn MA, Vandvik B. En mann med stive bein og bisarr gange. Tidsskr Nor Laegeforen 2007; 127: 1529-30.

11. Torbergsen T. Rippling muscle disease: a review. Muscle Nerve 2002; 999 (suppl 11): S103-7.

12. England JD, Gronseth GS, Franklin G et al. Distal symmetric polyneuropathy: a definition for clinical research: report of the American Academy of Neurology, the American Association of Electrodiagnostic Medicine, and the American Academy of Physical Medicine and Rehabilitation. Neurology 2005; 64: 199-207.

13. Krarup C. An update on electrophysiological studies in neuropathy. Curr Opin Neurol 2003, 16: $603-12$

14. Cho SC, Siao-Tick-Chong P, So YT. Clinical utility of electrodiagnostic consultation in suspected polyneuropathy. Muscle Nerve 2004; 30: 659-62.

15. Vedeler CA, Mellgren SI, Omdal R et al. Intravenøs lgG-behandling ved nevromuskulære sykdommer. Tidsskr Nor Legeforen 2010; 17: 1717-20.

16. Albertí MA, Alentorn A, Martínez-Yelamos S et al. Very early electrodiagnostic findings in GuillainBarré syndrome. J Peripher Nerv Syst 2011; 16 $136-42$.

17. Kokubun N, Nishibayashi M, Uncini A et al. Conduction block in acute motor axonal neuropathy. Brain 2010: 133: 2897-908.

18. Uncini A, Manzoli C, Notturno F et al. Pitfalls in electrodiagnosis of Guillain-Barré syndrome subtypes. J Neurol Neurosurg Psychiatry 2010; 81. $1157-63$

19. de Carvalho M, Dengler R, Eisen A et al. Electrodiagnostic criteria for diagnosis of ALS. Clin Neurophysiol 2008; 119: 497-503.

20. Daube JR. Electrodiagnostic studies in amy- trophic lateral sclerosis and other motor neuron disorders. Muscle Nerve 2000; 23: 1488-502.

21. Hammad M, Silva A, Glass J et al. Clinical, electrophysiologic, and pathologic evidence for sensory abnormalities in ALS. Neurology 2007 69: $2236-42$

22. Noto Y, Misawa S, Kanai K et al. Awaji ALS criteria increase the diagnostic sensitivity in patients with bulbar onset. Clin Neurophysiol 2012; 123: 382-5.

23. Sonoo M, Kuwabara S, Shimizu T et al. Utility of trapezius EMG for diagnosis of amyotrophic lateral sclerosis. Muscle Nerve 2009; 39: 63-70.

24. Antozzi C. Myasthenia gravis and myasthenic syndrome. Neurol Sci 2003: 24 (suppl 4): S260-3.

25. Titulaer MJ, Verschuuren JJ. Lambert-Eaton myasthenic syndrome: tumor versus nontumor forms. Ann N Y Acad Sci 2008; 1132: 129-34.

26. AAEM Quality Assurance Committee, American Association of Electrodiagnostic Medicine. Literature review of the usefulness of repetitive nerve stimulation and single fiber EMG in the electrodiagnostic evaluation of patients with suspected myasthenia gravis or Lambert-Eaton myasthenic syndrome. Muscle Nerve 2001; 24: 1239-47.

27. Cabrera Serrano M, Rabinstein AA. Causes and outcomes of acute neuromuscular respiratory failure. Arch Neurol 2010; 67: 1089-94.

28. Zink W, Kollmar R, Schwab S. Critical illness polyneuropathy and myopathy in the intensive care unit. Nat Rev Neurol 2009; 5: 372-9.

29. Guarneri B, Bertolini G, Latronico N. Long-term outcome in patients with critical illness myopathy or neuropathy: the Italian multicentre CRIMYNE study. J Neurol Neurosurg Psychiatry 2008; 79: 838-41.

30. Koch S, Spuler S, Deja M et al. Critical illness myopathy is frequent: accompanying neuropathy protracts ICU discharge. J Neurol Neurosurg Psychiatry 2011; 82: 287-93.

31. Ørstavik K, Svalheim S, Gunnarsson R et al. En alvorlig syk pasient som ikke våknet etter respiratorbehandling. Tidsskr Nor Legeforen 2012; 132: $822-5$.

Mottatt 10.2. 2012, første revisjon innsendt 22.7. 2012, godkjent 9.9. 2012. Medisinsk redaktør Merete Kile Holtermann. 